\title{
The role of the state in establishing a public cord blood stem cell bank
}

Allogeneic stem cell transplantation has become a curative treatment option for many patients with haematological malignancies, bone marrow failure syndromes, thalassaemia, sickle-cell disease and some rare disorders of the blood and bone marrow. Ideally, stem cells from the peripheral blood or bone marrow are sourced from sibling donors or from a matched unrelated donor if a sibling donor is not available. Alternatively, stem cells may be obtained from umbilical cord blood (UCB). The advantages of the latter over conventional sources of stem cells include that tissue matching requirements are less stringent, healthy donors are not exposed to invasive procedures, and transplants can be performed without delay.

Cord blood as a source of stem cells is rapidly changing the face of regenerative transplantation. ${ }^{1}$ The voluntary donation of cord blood cells to public UCB banks, resembling blood donation practice, is an example of a social justice health model that encompasses ethical citizenship and altruism. ${ }^{2}$ Van Rood's proposal on international transplant-sharing associations ${ }^{3}$ has been made a reality by public UCB banks. Such 'allogeneic tissue networks', formed by linking international registries, are scientifically and ethically easier to justify than private UCB banks that store autologous stem cells for exclusive use by the donor or a close relative. The likelihood that a child will require and receive its own cord blood as a transplant within 10 years of storage is very low, ${ }^{4}$ and the potential need for autologous use of a stored UCB unit is estimated to be between 0.04 and $0.0005 \% .^{5}$ The potential estimated need is not the same as the likelihood of actually receiving an UCB transplant; the latter is much lower. ${ }^{4}$ On the other hand, the probability of requiring an allogeneic stem cell transplantation is estimated to be $0.04 \%$ by age 20 years, $0.10 \%$ by age 40 , and $0.25 \%$ by age 70 . These are orders of magnitude higher than the

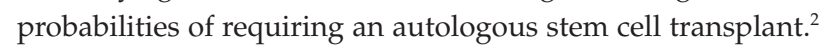
Nevertheless, several limitations to the use of UCB stem cells in adult patients must still be overcome; low stem cell dose is a significant challenge. ${ }^{6}$ Public UCB banks and systems such as the international bone marrow registries, which rely on voluntary peripheral blood stem cell donations, are positioned well to systematically address issues such as inequitable access to stem cell transplantation caused by stem cell shortages and the possible lack of genetic diversity of the stem cell bank. ${ }^{7}$

However, providing facilities to treat diseases with stem cells is complex and goes beyond simply fulfilling a medical need. A public UCB bank is not a medical necessity and should be regarded as the ideal rather than the norm. Such a view is persuasive, as public UCB banks are mostly confined to higherincome countries. ${ }^{1}$ The few lower-income countries that have established such banks include Argentina, China and Mexico. ${ }^{8}$

The estimated minimum requirement to satisfy the needs of South Africa is a public UCB bank with 10000 cord blood units representing the most common haplotypes that mirror the genetic diversity of the population. Such a bank would facilitate equitable access to a matched transplant, thus overcoming the limitations of the South African Bone Marrow
Registry, in which many of the ethnic groups in South Africa, particularly black donors, are significantly under-represented. ${ }^{9}$

The cost of establishing a public UCB bank is considerable, and each country should analyse the cost-benefit relative to the country's financial circumstances and health priorities..$^{10-12}$ This should take into account that the cost for a usable banked cord blood unit is about R9 000, ${ }^{13}$ which translates to R90 million to establish a South African public UCB bank with 10000 units. The cost-benefit to patients of such a programme becomes evident if one considers the optimistic estimate that the probability of using a banked unit will be $1 \%$ per year. ${ }^{7}$ Taking into account the likelihood of use of a unit and the cost of wastage of stored units, the cost of a transplanted unit will be at least R20 000. The initial capital outlay, however, will be recovered in due time if the programme continues to expand and the cord blood units can be sold on a cost-recovery basis. ${ }^{12}$

Consequently, the high cost of establishing and maintaining a public UCB bank must be seen in the context of its actual and potential therapeutic use. It is estimated that currently about 1:100 000 of the population per year may benefit from a regenerative transplant. Such a level of service is not yet available in any country, and at best only $50 \%$ of the needs for haemopoietic cell transplantation are currently satisfied. ${ }^{1}$ To date, this universal lack of availability of cord blood as a source of stem cells has limited the total UCB transplants to about 15000 worldwide. $^{6}$

The crux of the matter, therefore, is whether establishing a public UCB bank is a health priority in South Africa. The Bill of Rights ${ }^{14}$ states that all have the right of access to health care services. However, this is qualified by the statement that the state must take reasonable legislative and other measures, within its available resources, to achieve the progressive realisation of such a right. Consequently, policy decisions on health priorities and how to spend the funds available for health care are not only medical scientific issues but societal decisions, as recognised by the South African National Health Act. ${ }^{15}$ The Act broadly states which health issues should be addressed, and provides for the establishment of a National Health Council to advise the Minister on policy concerning matters that affect the health of the population and a National Consultative Health Forum to facilitate communication and interaction among stakeholders. It also embraces policy, priorities and norms relating to the equitable provision and financing of health services, and the responsibilities for health of the individuals and the public and private sector. Preventive medicine and the provision of basic health care are the current priorities in South Africa. ${ }^{16}$ It is therefore unlikely that the state will consider an expensive project such as a public UCB bank that will benefit relatively few patients as a health priority.

How best can this discussion be taken forward? The state is the regulatory authority for stem cell banks, private and public, thus ensuring quality standards and ethical practices. The Department of Health also formulates high-level national policies based on the health needs and priorities of the 
country. The state should recognise the growing importance of regenerative medicine and accept its responsibility to play an active role in determining how this need can best be satisfied in the South African context. The state should recognise that the private sector could play an important role in establishing stem cell banks and may share the financial burden.

To ensure good policy and decision making it is therefore suggested that the state should take the initiative and convene a suitable forum where the national policy on establishing UCB banks can be discussed. Ways in which a public UCB bank can possibly be funded, and whether regenerative medicine should be regarded as a health priority, should be considered. The respective roles of the state and the private sector in establishing and funding a public cord blood bank, possibly on a fee-for-service basis, could be debated.

Such a facility would benefit South African patients and address moral and ethical issues related to inequitable medical services, and the disparate donor/recipient availability of stem cells in this country.

\section{Vernon J Louw}

Division of Clinical Haematology

Department of Internal Medicine

Faculty of Health Sciences

University of the Free State

Bloemfontein
References

. Jain KK. Cell therapy - technologies, markets and companies (2007). http://pharmabiotech ch/reports/celltherapy (accessed 7 July 2007).

2. Titmuss RM. The Gift Relationship: From Human Blood to Social Policy. New York: New Press, 1997.

3. Van Rood JJ. A proposal for international cooperation in organ transplantation

Eurotransplant. In Curtoni ES, Mattiuz PL, Tosi RM, eds. Histocompatibility Testing. Baltimore: Williams \& Wilkins, 1967 .

4. Nietfeld JJ, Pasquini MC, Logan BR, Verter F, Horowitz MM. On the probability of using cord blood [Letter]. Biol Blood Marrow Transplant 2008; 14: 724-725.

5. Nietfeld JJ, Pasquini MC, Logan BR, Verter F, Horowitz MM. Lifetime probabilities of hematopoietic stem cell transplantation in the US. Biol Blood Marrow Transplant 2008; 14 316-322.

6. Frey MA, Guess C, Allison J, Kurtzberg J. Umbilical cord stem cell transplantation. Semin Oncol Nurs 2009; 25: 115-119.

Ruff P, Schlapoff T, du Toit E, Heyns AduP. The South African Bone Marrow Registry (SABMR) and allogeneic bone marrow transplantation. S Afr Med J 2008; 98: 516-520.

8. Flegel K. Ten reasons to make cord blood stem cells a public good. Can Med Assoc J 2009; 180: 1279

9. The South African Bone Marrow Registry. Chairman's report 2009. http://www.sabmr.co.za/ chairmans-report/ (accessed 23 September 2009).

10. Howard DH, Maiers M, Kollman C, Logan B, Gragert L, Setterholm M. A cost-benefit analysis of increasing cord blood inventory levels. In: Meyer EA, Hanna K, Gebbie K, eds. Cord Blood: Establishing a National Haematopoietic Stem Cell Bank Program. Washington DC: National Academic Press, 2005.

11. Health Council of the Netherlands. Ethical Aspects of Cost-utility Analysis. 4th Forum of National Ethical Councils in EU Countries, Amsterdam, 22 December 2004. Presentations and discussion. The Hague: Health Council of the Netherlands, 2005, publication No. A05/01.

12. Howard DH, Meltzer D, Kollman C, Maiers M, Logan B, Gragert L, Setterholm M, Horowitz MM. Use of cost-effectiveness analysis to determine inventory size for a national cord blood bank. Med Decis Making 2008: 28: 243-253.

13. Querol S. Cord blood banking: ethical and cost-benefit aspects. ISBT Science Series 2007; 2: $85-90$

14. Constitution of the Republic of South Africa, 1996. Chapter 2 - Bill of Rights. http://www info.gov.za/documents/constitution/1996/96cons2/htm (accessed 7 July 2007).

15. National Health Act, 2004 (Act No. 61 of 2003), Section 3(e). Government Gazette 2004; 469 (26595). http://www.doh.gov.za/docs/index.html (accessed 23 September 2009).

16. Department of Health. Strategic Priorities for the National Health System 2004 - 2009. http:// www.doh.gov.za/docs/policy-f.html (accessed 23 September 2009).

\section{Anthon du P Heyns}

Department of Haematology and Cell Biology

Faculty of Health Sciences

University of the Free State

\section{A Pan-African Clinical Trials Registry for the specific needs of triallists on the continent}

Clinical trials provide the best evidence for which health care interventions work, which do not, and which may be harmful. ${ }^{1}$ Ideally we aim to base our clinical practice on the results from well-conducted trials. For us to be able to do so, all trial reports must be available in the public domain and accurately reflect the methods and the results of clinical trials.

Trial reports may not be available publicly due to publication bias - the tendency for positive and significant trial results to be published preferentially and for negative or neutral trial results to be refused, or withheld from, publication. ${ }^{2}$ Prospective trial registration arose out of the need to reduce the effects of publication bias and to encourage greater public disclosure, particularly in industry-led trials. ${ }^{3}$ Prospective registration encourages triallists to record the aim, objectives, outcomes and planned analysis of their trial on a clinical trial register before enrolling the first patient. After successful registration the trial is allocated a unique identification number.

Clinical trial registration has become an important part of the clinical trial process since the Ministerial Summit on Health Research called on the World Health Organization (WHO) in 2004 to establish 'a network of international clinical trial registers to ensure a single point of access and the unambiguous identification of trials'. In 2005 this call was endorsed by the 58th World Health Assembly and supported by the International Committee of Medical Journal Editors (ICMJE), who updated their statement so that only trials registered on WHO-endorsed primary registers would be 